\title{
Recycled dead chicken meal in low cost practical diets for African catfish (Clarias gariepinus) fingerlings
}

\author{
${ }^{1 *}$ Agbabiaka. L.A, ${ }^{2}$ Ezeafulukwe .C.F and ${ }^{1}$ Ekeledo C.B \\ ${ }^{1}$ Department of Fisheries Technology, Federal Polytechnic ,Nekede - Owerri, \\ Nigeria \\ ${ }^{2}$ Department of Fisheries/Marine Technology, Imo State Polytechnic - Owerri, \\ *adegokson2@yahoo.com
}

\begin{abstract}
Ten weeks feeding trial was conducted on growth response and economic benefit of replacing fishmeal with recycled dead chicken meal (DCM) in the diets of African catfish ( Clarias gariepinus ) fingerlings. Four isonitrogenous diets containing $40 \%$ crude protein were formulated in which DCM replaced fishmeal at $0,30,50$ and $100 \%$ coded as $\mathrm{DCD}_{1}, \mathrm{DCD}_{2}, \mathrm{DCD}_{3}$ and $\mathrm{DCD}_{4}$ respectively. Results from the feeding trial indicated that all the fish fed the test ingredient (DCM) performed significantly $(p<0.05)$ better than those fed the reference diet $\left(D C D_{1}\right)$. However, the feed intake and body weight gain increased linearly with increased DCM in the diets $(p<0.05)$. There was no significant $(p>0.05)$ difference between fish fed reference diet (control) and those fed the DCM based diets in feed conversion ratio and protein efficiency ratio respectively. Nevertheless, this experiment revealed that recycled dead chicken meal can totally replaced fishmeal in the low cost and efficient diets for Clarias gariepinus without compromising performance.
\end{abstract}

Keywords: Recycled, dead chicken meal, catfish, low-cost, performance.

\section{INTRODUCTION}

The utilization of unorthodox feedstuffs of plant origin in monogastrics nutrition have been limited because of their inherent anti-nutrients such as alkaloids, glycosides, oxalic acids, phytate, protease inhibitors, haematoglutinin, saponins, mimosine, cyanoglycosides and linamarin ; coupled with their relatively low digestibility and deficiencies in sulphuramino acids such as lysine and methionie (Oyelese et al., 1999; Omitoyin and Faturoti, 2000; Sogbesan et al., 2006).

Several attempts have been made towards the use of non-conventional animal protein feed resources with some successes. These include earthworm and Termite (Macrotermes subhyalinus) meals (Sogbesan and Ugwumba, 2008), maggot meal (Sogbesan et al., 2006), chicken offal meal (Faturoti, 2000) and Phane (Imbrasia belina) insect (Moreki et al. 2012) to replace fish meal that has been the main source of animal protein in diets of fish and livestock primarily due to its high digestibility and rich essential amino-acids (EAAs) especially sulphur-amino acids that are deficient in most plant proteins. Essential amino-acid cannot be synthesized in the required quantity necessary for fish growth and tissue development, hence, must be fortified in diets of fish and livestock (Agbabiaka, 2010a; Abowei and Ekubo, 2011).

FAO (2009) has reported that about 2.0 billion people globally are suffering from chronic malnutrition which manifested in diseases such as kwashiorkor, marasmus and other related metabolic problems. However, about $60 \%$ of these population (i.e.1.2 billion) are from developing countries of Asia, Africa and Latin America, where the most prevalent cause of death in post-weaned infants is protein malnutrition (FAO, 2009). Fish have been identified to be the solution to problem of malnutrition due to its availability, general acceptance, nutritional quality and the relatively cheap price as a source of animal protein (Agbabiaka et al., 2012; Bene and Heck, 2002). Despite the promises of aquaculture as stated above, its development has been hampered due to inadequate quantity and quality of feedstuffs especially oil seeds and fishmeal at economic prices; often, fishmeal in developing countries such as Nigeria are imported; which perhaps made the prices far beyond the reach of an average farmer in Nigeria and other sub-Saharan Africa. 
Agric. Biol. J. N. Am., 2013, 4(3): 181-185

Chicken (Gallus domesticus) is believed to have originated from South-east Asia; it is reported to have evolved from reptiles because of possessive features like scales (Uwa and Ene, 2000). Re-cycled chicken meal is the dry rendered product from a combination of chicken flesh and skin accompanying bone derived from whole carcass of chicken exclusive of feathers, which has been ground or otherwise reduced in particle size (AAFCO, 2010). Poultry industry has been under-going rapid development in Nigeria in the last two decades while government support for agricultural sector towards meeting the Millennium Development Goals (MDGs) cannot be overemphasized.

Usually, about $10 \%$ allowance is usually added to chicks order in poultry production to compensate for mortality hence, estimated quantity of dead chicken produced in Nigeria and other developing countries could be in excess of $6-10 \%$ of the total chicken/poultry production at any point in time. This often constitutes environmental menace especially in rural areas where there is no technology for processing. There is currently no information on the use of dead chicken meal in catfish production in Nigeria, hence, this research was aimed at evaluating the replacement value of dead chicken meal for fishmeal in diets of African catfish.

\section{MATERIALS AND METHODS}

Location of study and sample preparation: The research was conducted at the Teaching and Research farm, Federal Polytechnic, Nekede, Owerri, Nigeria. The freshly dead chickens certified by the Resident veterinary doctor were collected from Urban Fish and Livestock Farms limited, Owerri, Nigeria. The dead chickens were scalded in hot water of about $80^{\circ} \mathrm{C}$ for $20-25$ seconds; carcasses were deplumaged, cut into chunks and pressure- cooked at $100^{\circ} \mathrm{C}$ for 30 minutes (wet rendering) to curtail microbial load / contamination prior to oven-drying at $75^{\circ} \mathrm{C}$ for 18 hours. The dried dead chickens were passed through a mini harmer mill to produce dead chicken meal (DCM) to facilitate pelleting.

Feed formulation and Analysis: Sample of the DCM produced was analyzed for proximate composition prior to mixing with other feedstuffs to produce four diets $(\mathrm{CP}=40 \%)$ where $\mathrm{DCM}$ replaced fish meal at 0, 30, 50 and $100 \%$ coded as DCD1, DCD2, DCD3 and DCD4 respectively (table 2). The control diet contained no dead chicken meal (DCM). The formulated practical diets were pelleted using locally fabricated pelleting machine with die $2 \mathrm{~mm}$. Pelleted diets were sun-dried for 4 days until crispy, packed into air-tight polythene bags and labelled accordingly. Sample of each diet was taken for proximate composition using standard methods (AOAC, 2000).

Experimental fish and feeding: One hundred and twenty African catfish (Clarias gariepinus) fingerlings with mean body weight $6.5 \pm 0.3 \mathrm{~g}$ were purchased from a commercial hatchery at Owerri, Nigeria. They were acclimated for a week and fed the control diet; thereafter, fish were randomly allotted at 30 fish per treatment to the four practical diets in a completely randomized design. Each treatment was replicated trice at the rate of 10 fish per hapa, making a total of 12 units in all. The fish were reared in hapa net measuring $1 \times 1 \times 1 \mathrm{~m}$ suspended in an outdoor cistern $(5 \times 4 \times 1.2 \mathrm{~m})$ and fed at $3 \%$ body weight daily shared between 8-9am and 5-6pm. All the fish were starved for 24hours prior to the commencement of the feeding trial which lasted for 10 weeks.

Data collection and analysis: The experimental fish were batch weighed on replicate basis at the beginning of the study and bi-weekly thereafter using digital weighing machine. Fish in each hapa were weighed between 6-7am on sampling days to curtail stress and were returned into their respective hapas after taking the measurements. Feeding rate was always adjusted to the new body weight fortnightly and stale water drained off pond and re-filled from the bore-hole water at the farm complex. Data on feed intake, weight gain and feed conversion ratio were subjected to one-way analysis of variance as outlined by Snedecor and Cochran (1978).

\section{RESULTS AND DISCUSSION}

The results of the nutrients analysis showed that Dead chicken meal (DCM) contained $52.68 \%$ crude protein , $6.56 \%$ fat, while values of $12.36,1.21$ and $19.20 \%$ were recorded for ash, crude fibre and Nitrogen free extract respectively. This indicated that the concentration of crude protein in DCM is higher than the range of $43.10-49.50 \%$ in Termite (Macrotermes subhyalinus) meal and $41.30-47.80 \%$ found in tadpole (Bufo maculata) meal but lower than 60- $69 \%$ recorded for earthworm and garden snail meals (Odibo,1997 ; Siera, 1998 ; Sogbesan and Ugwumba, 2008). However, it compared favourably with value of $56.80 \%$ in Phane insect (Imbrasia belina) by Moreki et al. (2012). The fat content of $6.56 \%$ in DCM is similar to that of earthworm and 
garden snail with lipid values of 5.9 and $7.9 \%$ respectively. The Ash concentration (12. 36\%) also compared favourably with the value of $8.9 \%$ in earthworm according to Sogbesan and Ugwumba (2008).

The reason why the groups of fish fed DCM based diets performed better than the control group fed fishmeal as sole animal protein source cannot be totally explained. The weight gains of fish fed $D D_{2}$ up to $\mathrm{DCD}_{4}$ were superior $(\mathrm{p}<0.05)$ to the control $\left(D_{C} D_{1}\right)$ group. Similar observation was reported when maggot meal was fed to hybrid Clariid catfish (Sogbesan et al., 2006). Nevertheless, all the diets supported growth of the trial fish. This was an indication that all the diets met the nutrient requirements ( $C P=35-40 \%)$ of the African catfish in question to promote growth and tissue development (Fagbenro, 1992; Faturoti, 2000; Agbabiaka, 2010b). It has also been reported that biological value of any protein source does not only depend on its amino acid profile but also on digestibility (Massumotu et al., 1996).

Table 1: Proximate composition of recycled dead chicken meal

\begin{tabular}{lc}
\hline PARAMETERS & CONCENTRATION (\%) \\
\hline Moisture & 7.99 \\
Crude protein & 52.68 \\
Fat & 6.56 \\
Fibre & 1.21 \\
Ash & 12.36 \\
Nitrogen free extract & 19.20 \\
\hline
\end{tabular}

Table 2: Gross composition of experimental diets

FEED INGREDIENTS

\begin{tabular}{lllll}
\hline Dead chicken meal & - & 8.4 & 14 & 28 \\
Fishmeal & 28 & 19.6 & 14 & - \\
Soybean meal & 40 & 40 & 40 & 40 \\
Maize & 26 & 26 & 26 & 26 \\
Bone meal & 2.5 & 2.5 & 2.5 & 2.5 \\
Vegetable oil & 2.0 & 2.0 & 2.0 & 2.0 \\
Salt & 0.25 & 0.25 & 0.25 & 0.25 \\
Vitamin premix & 0.25 & 0.25 & 0.25 & 0.25 \\
Lysine & 0.50 & 0.50 & 0.50 & 0.50 \\
Methionine & 0.50 & 0.50 & 0.50 & 0.50 \\
Total & 100 & 100 & 100 & 100 \\
\hline
\end{tabular}


Agric. Biol. J. N. Am., 2013, 4(3): 181-185

\begin{tabular}{llllr} 
Proximate composition of test diets & & & & \\
Moisture & 7.91 & 7.64 & 7.28 & 7.63 \\
Crude protein & 39.68 & 39.27 & 39.11 & 38.68 \\
Fat & 4.87 & 4.53 & 4.48 & 4.37 \\
Fibre & 4.56 & 4.73 & 4.57 & 4.82 \\
Ash & 10.30 & 10.95 & 10.43 & 10.55 \\
Carbohydrate & 32.87 & 32.88 & 33.16 & 33.95 \\
\hline
\end{tabular}

Table 3: Growth performance of fish fed recycled dead chicken based diets

\begin{tabular}{lcccc}
\hline \multirow{2}{*}{ PARAMETERS } & \multicolumn{3}{c}{ Dietary treatments } \\
& DCD $_{\mathbf{1}}$ & $\mathbf{D C D}_{\mathbf{2}}$ & $\mathbf{D C D}_{\mathbf{3}}$ & $\mathbf{D C D}_{\mathbf{4}}$ \\
\hline Mean initial weight(g) & 6.80 & 6.40 & 6.20 & 6.90 \\
Mean final weight (g) & 52.10 & 60.60 & 58.20 & 63.50 \\
Mean weight gain (g) & $45.30^{\mathrm{b}}$ & $54.20^{\mathrm{a}}$ & $52.00^{\mathrm{a}}$ & $56.60^{\mathrm{a}}$ \\
Total feed intake (g) & $43.15^{\mathrm{b}}$ & $56.05^{\mathrm{ab}}$ & $51.36^{\mathrm{ab}}$ & $65.40^{\mathrm{a}}$ \\
Specific growth rate (\%day $\left.{ }^{-1}\right)$ & $1.26^{\mathrm{a}}$ & $1.39^{\mathrm{b}}$ & $1.38^{\mathrm{b}}$ & $1.37^{\mathrm{b}}$ \\
Feed conversion ratio (FCR) & $0.95^{\mathrm{a}}$ & $1.03^{\mathrm{a}}$ & $0.99^{\mathrm{a}}$ & $1.16^{\mathrm{a}}$ \\
Protein efficiency ratio (PER) & $1.05^{\mathrm{a}}$ & $0.96^{\mathrm{a}}$ & $1.01^{\mathrm{a}}$ & $0.87^{\mathrm{a}}$ \\
Mean growth rate (g) & 0.65 & 0.77 & 0.74 & 0.81 \\
Cost per 25kg feed (N) & $\mathbf{4 9 9 9 . 2 5}$ & $\mathbf{3 9 4 6 . 2 5}$ & $\mathbf{3 2 4 6 . 2 5}$ & $\mathbf{1 4 9 6 . 2 5}$ \\
\hline
\end{tabular}

\section{REFERENCES}

A.A.F.C.O (2010). Association of American feed control officials : Feed inspection manual. 122p

Abowei J.F.N and A.T. Ekubo (2011). A Review of Conventional and Unconventional Feeds in Fish Nutrition. British Journal of Pharmacology and Toxicology 2(4): 179-191

Agbabiaka L.A. (2010a): Aquaculture and Pond management in the tropics. Vintage Books limited, Owerri. 111p

Agbabiaka, L.A. (2010b): Evaluation of some under utilized protein feedstuffs in diets of Clarias gariepinus fingerlings. International Journal of Tropical Agric. and Food systems. 4(1): 10-12

Agbabiaka L. A., Amadi A. S., Madubuko C. U., Nwankwo F. C. and Ojukannaiye A. S. (2012). Assessment of nutrients and sensory qualities of brine pre-treated catfish smoked with two different woods. African Journal of Food Science 6(7): 245-248

Bene, C. and Heck. S .(2002): Fisheries and the millennium development goals. Solution for Africa. NAGA 28: 8 13

FAO (2009). Food Security, Concepts and Measurement. In: Food Security: The Science, Sociology and Economics of Food Production and Access to Food.
Fao.org. http://www.org./docrep/005/y467/e06.htm Retrieved: 03/11/2011.

Fagbenro, O.A. (1992). Utilization of cocoa pod husk in low-cost diets by the Clariid catfish (Clarias isheriensis Sydenham). Aquaculture and Fisheries Management, 23:175-182.

Faturoti E.O. (2000). Utilization of raw and parboiled chicken offal in catfish (Clarias gariepinus) diets. www.trifas.org. Aquafied 1(1): 7-11.

Lan, C.C. and Pan, B.S. (1993). In vitro digestibility simulating the proteolysis of feed protein in mid-gut of gross shrimps. Aquaculture 109: 50-707.

Massumotn, T., Ruchmat, T. and Ito, Y. (1996). Amino acid availability values for several protein sources for yellow tail Seriola quinqueradiate. Aquaculture 146: 109-119.

Moreki J. C., Tiroesele B. and Chiripasi S. C.(2011). Prospects of Utilizing Insects as Alternative Sources of Protein in Poultry Diets in Botswana: a Review . J Anim Sci Adv 2012, 2(8): 649-658

Odaibo, B.A. 1997. Snail and Snail farming, Nigeria: Edible land snail. Stirling-Horden Publishers (Nig.) Ltd. Lagos, 29 pp.

Omitoyin, B.O. and Faturoti, E.O. (2000). Effect of raw and parboiled chicken offal in the diet of Clarias gariepinus. Aquabyte, 1: 20-25. 
Agric. Biol. J. N. Am., 2013, 4(3): 181-185

Oyelese, O.A., Taiwo, V.O., Ogunsanmi, A. and Faturoti, E.O. (1999). Toxicological effect of cassava peels on haematology, serum biochemistry, tissues pathology of Clarias gariepinus (Burchell, 1822) fingerlings. Tropical Veterinary, 17: 17-30.

Seira, A.B. 1998. The use of golden snail (Pomacea sp.) as animal feed in the Philippines. Voedings Magazine, 11(6): 40-43.

Snedecor, G.W. and Cochran. W.G (1978). Statistical Methods. 6th edition. Iowa State University Press, Ames, lowa, USA
Sogbesan A.O., Adebisi, A.A., Falaye B.A., Okaeme B.N. and Made C.T. (2006). Some aspects of dietary protein deficiency diseases in semi-intensive cultured fishes. A review Journal of Arid zone fish. 2(1): 80-89.

Sogbesan. A.O. and Ugumba A.A.A. (2008). Nutritional values of some non-conventional Animal protein feedstuffs used as fishmeal supplement in Aquaculture practices in Nigeria. Turkish Journal of fisheries and Aquatic sciences; 8: 159-164.

Uwa, U. and Ene, N. (2000). Fundamentals of general biology. John Jacob's Classic Publishers Ltd. Enugu Nigeria. 196p 